University of Nebraska - Lincoln

DigitalCommons@University of Nebraska - Lincoln

Faculty Publications from the Harold W. Manter Laboratory of Parasitology

2-1978

\title{
Permanent Light Microscopy Slides of Eimeria nieschulzi Oocysts
}

Alan A. Marchiondo

University of New Mexico - Gallup Campus

Donald W. Duszynski

University of New Mexico, eimeria@unm.edu

Follow this and additional works at: https://digitalcommons.unl.edu/parasitologyfacpubs

Part of the Parasitology Commons

Marchiondo, Alan A. and Duszynski, Donald W., "Permanent Light Microscopy Slides of Eimeria nieschulzi Oocysts" (1978). Faculty Publications from the Harold W. Manter Laboratory of Parasitology. 130. https://digitalcommons.unl.edu/parasitologyfacpubs/130

This Article is brought to you for free and open access by the Parasitology, Harold W. Manter Laboratory of at DigitalCommons@University of Nebraska - Lincoln. It has been accepted for inclusion in Faculty Publications from the Harold W. Manter Laboratory of Parasitology by an authorized administrator of DigitalCommons@University of Nebraska - Lincoln. 


\section{Permanent Light Microscopy Slides of Eimeria nieschulzi Oocysts}

Flotation techniques commonly used in recovering coccidian oocysts from fecal debris for examination and study cause plasmolysis and collapse of the inner oocyst wall on prolonged contact with saturated salt or sugar solutions (Davis, 1973, in Hammond and Long (eds.), The Coccidia, Univ. Park Press, Baltimore, p. 411-458). Although the coverslip can be sealed with Vaseline to prevent drying, oocysts only retain their structural integrity in these solutions for short periods $(\sim 12 \mathrm{hr}$ or less). Therefore, slides obtained by flotation techniques have limited usefulness for studying oocysts, especially when the number of parasites is small. We describe here two methods for the preparation of light microscopy slides of Eimeria nieschulzi oocysts.

Suspensions of sporulated oocysts were treated prior to fixation by six different methods: $5 \% \mathrm{CO}_{2}$ at $37 \mathrm{C}$ for $30 \mathrm{~min}, 1 \mathrm{hr}, 2 \mathrm{hr}$; $30 \%$ hypochlorite solution at $22 \mathrm{C}$ for $1 \mathrm{hr}$; Lillie solution (Humason, 1972, Animal Tissue Techniques, Freeman, San Francisco, p. 31) at $22 \mathrm{C}$ for $24 \mathrm{hr}$; or $4 \%$ EDTA (Hayat, 1972,
Basic Electron Microscopy Techniques, Van Nostrand, New York, p. 23) at $22 \mathrm{C}$ for $24 \mathrm{hr}$. Each treated oocyst suspension was then fixed by the following agents for $18 \mathrm{hr}$ at $22 \mathrm{C}$ : $10 \%(\mathrm{v} / \mathrm{v})$ aqueous acrolein; $4 \%$ formalin; 3 or $15 \%(\mathrm{v} / \mathrm{v}$ in $0.2 \mathrm{M}$ cacodylate buffer) glutaraldehyde with and without postfixation in $2 \%(\mathrm{w} / \mathrm{v}$ in $0.2 \mathrm{M}$ cacodylate buffer) $\mathrm{OsO}_{4}$ for $2 \mathrm{hr}$; and Karnovsky's fluid (Karnovsky, 1965, J Cell Biol 27: 137A-138A) with and without postfixation in $2 \% \quad \mathrm{OsO}_{4}$ (as above).

A suspension of oocysts from each of the treatment-fixative combinations was collected on a $1 \mathrm{~mm}^{2}$ piece of $0.45 \mathrm{~m} \mu$ Millipore filter (Millipore Filter Corp., Bedford, Mass.) and covered with a thin layer $(\sim 1 \mathrm{~mm})$ of $1.5 \%$ $(\mathrm{w} / \mathrm{v})$ Bacto-agar (Difco Laboratories, Inc., Detroit, Michigan) at 45 C. Samples from each combination were stained at $22 \mathrm{C}$ for 6 to $8 \mathrm{hr}$ with the following: $5 \%$ aqueous $(\mathrm{w} / \mathrm{v}$ ) acid fuchsin; $0.1 \%$ aqueous ( $\mathrm{w} / \mathrm{v}$ ) acridine orange; $1 \%$ aqueous $(\mathrm{w} / \mathrm{v})$ alcian blue; $1 \%$ aqueous $(\mathrm{w} / \mathrm{v})$ gentian violet; $1 \%$ aqueous 


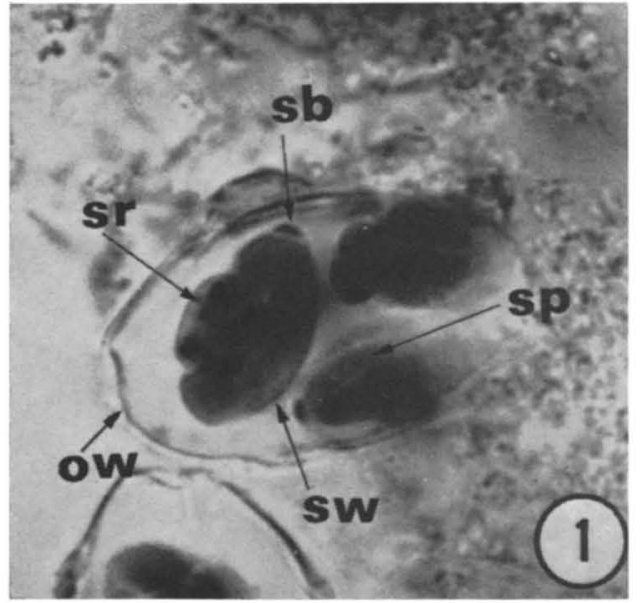

Figure 1. Photomicrograph of sporulated Eimeria nieschulzi oocyst, $\times 2,300$. Prepared by Method 1 (see text); note sporocyst showing Stieda body and sporocyst residuum. Abbreviations: ow, oocyst wall; sb, Stieda body; sp, sporozoite; sr, sporocyst residuum; and sw, sporocyst wall.

(w/v) methylene blue-azure II; Paragon Multiple Stain (Paragon C and C. Co., Inc., 190 Willow Avenue, Bronx, New York); 2\% aqueous $(\mathrm{w} / \mathrm{v})$ safranin $\mathrm{O}$; and $0.5 \%$ aqueous $(\mathrm{w} / \mathrm{v})$ thionin. The samples were dehydrated in ethanol and two changes of propylene oxide and embedded in one of the following: Araldite-502; Epon-812; Epon-812: Araldite502 (60:40); Glycol methacrylate; or Spurr's medium (Spurr, 1969, J Ultrastruct Res 26: 31-43) using standard infiltration techniques (Hayat, 1970, Principles and Techniques of Electron Microscopy: Biological Applications, Vol. 1, Van Nostrand-Rienhold, New York, p. 145-179). Samples were placed on $25 \times 75$ $\mathrm{mm}$ glass microscope slides and a $22 \mathrm{~mm}^{2}$ glass coverslip was affixed with media which was polymerized at $45 \mathrm{C}$ for $18 \mathrm{hr}$.

Two combinations of methods were found to be superior to produce permanent light microscopy slides of $E$. nieschulzi oocysts: 1 . Oocysts treated with $5 \% \mathrm{CO}_{2}$ at $37 \mathrm{C}$ for 30 min, fixed in $15 \%$ glutaraldehyde at $22 \mathrm{C}$ for $18 \mathrm{hr}$, postfixed in $2 \% \mathrm{OsO}_{4}$ at $22 \mathrm{C}$ for 2 $\mathrm{hr}$ and embedded in Epon-812. 2. Oocysts treated with $5 \% \quad \mathrm{CO}_{2}$ at $37 \mathrm{C}$ for $30 \mathrm{~min}$, fixed in Karnovsky's fluid at $22 \mathrm{C}$ for $18 \mathrm{hr}$, postfixed in $2 \% \mathrm{OsO}_{4}$ at $22 \mathrm{C}$ for $2 \mathrm{hr}$ and embedded in Spurr's medium.

Oocysts treated by these two methods were morphologically similar to normal oocysts when examined by light microscopy. The percent shrinkage in oocysts and sporocyst dimensions from treatment by the two methods was $\leqslant 11 \%$, 15 months after polymerization.

Although $\mathrm{OsO}_{4}$ was not always necessary as a fixative, postfixation increased cellular detail and oocyst contrast by acting as a structural stain especially to the Stieda body and sporocyst residuum (Fig. 1). The sporozoites were also stained by the osmium.

None of the dyes used stained oocyst structure; however, the agar retained some stain and provided a background for the oocysts. The Millipore filter was rendered transparent by the propylene oxide during the dehydration process.

Oocysts embedded in Epon-812 and Spurr's media had $91 \%$ and $89 \%$ intact sporocysts, respectively, with good to excellent cellular detail. Spurr's medium became dark yellow in color after polymerization but Epon-812 hardened colorless. All media tested caused moderate bubble formation during polymerization.

The methods described here allow for the preparation of light microscopy slides of coccidian oocysts and thus, provide a durable sample and record for research and teaching. These methods used only one species, E. nieschulzi; however, it is likely that use of other coccidian oocysts would produce similar results.

Millipore filters have been utilized as a solid substrate for cell cultures and viruses in ultrastructural studies (McCombs et al., 1968, J Cell Biol 36: 231-243). The methods described here have modified this procedure for use in light microscopy. In addition, these methods may be used to embed coccidia for electron microscopy instead of pelleting the organisms with tissue culture cells (Speer and Duszynski, 1975, J Protozool 22: 476-481).

Alan A. Marchiondo and Donald W. Duszynski, Department of Biology, The University of New Mexico, Albuquerque 87131 